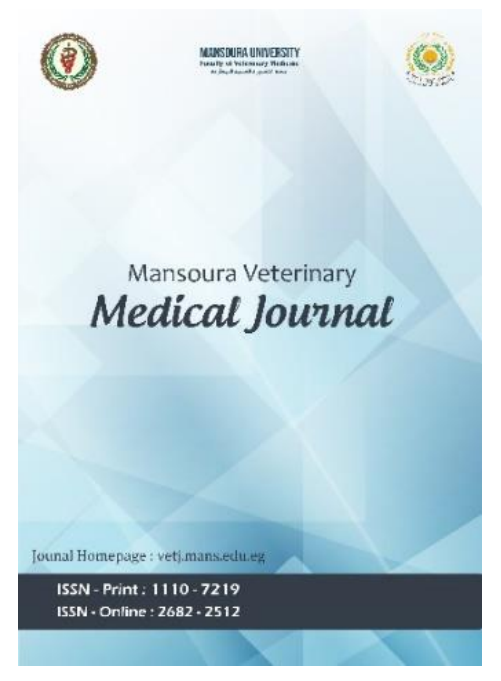

\title{
Postnatal toxicity of copper oxychloride in lactating female albino rats
}

Mohamed S. Abomosallam1, Mahmoud M. Elalfy, Fathy R. Sleem

To cite this article: Mohamed Abomosallam, Mahmoud Elalfy, Fathy Sleem. Postnatal toxicity of copper oxychloride in lactating female albino rats. Mansoura Veterinary Medical Journal 2020; 21, 3: 91-98.

To link to this article: $\mathrm{https}: / /$ doi.org/10.35943/mvmj.2020.21.316

Published online: 29 September 2020

Submit your article to this journal

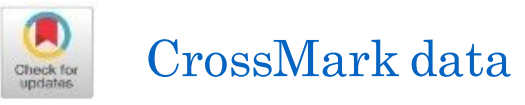




\section{Postnatal toxicity of copper oxychloride in lactating female albino rats}

Mohamed S. Abomosallam¹ ${ }^{1}$ Mahmoud M. Elalfy, Fathy R. Sleem

Department of Forensic Medicine and Toxicology, Faculty of Veterinary Medicine, Mansoura University, Egypt.

\section{ARTICLE HISTORY}

\section{Received: 15.06 .2020}

Revised: 17.09 .2020

Accepted: 18.09.2020

Address correspondence to Fathy Radwan E-mail:

fathysleem@mans.edu.eg

\section{ABSTRACT}

\begin{abstract}
Objective: To evaluate the postnatal toxicity of copper oxychloride (COC) in lactating female albino rats.

Design: Randomized controlled experimental study.

Animals: Eighteen pregnant female albino rats weight $150 \pm 10$ g and 6-7 week old.

Procedures: Eighteen pregnant female albino rats were divided into 3 groups treated orally with copper oxychloride $0,73.5,147 \mathrm{mg} / \mathrm{kg}$ (equivalent $1 / 20$ and $1 / 10$ of LD $_{50}$ ) daily from first day of parturition for 21 days. Female rats and its offspring were euthanized at 21 days of treatment. The postnatal toxic effect in the neonates and dams were estimated through biochemical biomarkers as metabolic and oxidative stress biomarkers, histopathological and hematological evaluation.

Results: There was a significant increase in liver enzymes activities as ALT and GGT and oxidative stress biomarker as MDA $(P<0.05)$ in both suckling pups and lactating dams beside decrease the level of metabolic biomarkers as glucose, total protein and cholesterol $(P<0.05)$. Additionally, antioxidant enzymes as SOD and CTA $(P<0.05)$ were reduced significantly in the treated groups in a dose dependent manner in comparison to control group. Moreover the histopathological revealed that Dams treated with $\mathrm{COC}$ at both doses shown degenerative changes and intralobular histiocytic infiltration with intralobular fibroblastic proliferation in the hepatic tissue. Neuronal necrosis, neuronophagia and astrocytosis in the brain tissue with degenerative changes of purkinje cells in cerebellum. Fibrous tissue proliferation of renal glomeruli with degenerative changes in renal tubular epithelium and marked lymphoid depletion in the splenic tissue in dose dependent manner. While Suckling pups of treated dams with different doses of COC shown focal histiocytic and lymphocytic infiltration besides congestion of portal vein and margination of leukocytes, focal edema in the neuropils with focal hemorrhagic areas in the brain tissue, degeneration in the renal glomeruli and severe lymphoid depletion with congestion of the splenic sinusoids in dose dependent manner.

Conclusion and clinical relevance: The potential postnatal toxic effect of copper oxychloride in neonates and lactating female albino rats through transmammary transmission in milk clarified from biochemical and histopathological evaluation of dams and its pups.
\end{abstract}

Keywords: Copper oxychloride, Fungicide, Postnatal Toxicity, Lactating female and albino rats.

\section{INTRODUCTION}

Pesticides can be classified according to the specific target into insecticides, herbicides, molluscicides, nematicides, rodenticides, fungicides and others. The application of such of such chemicals increased in the recent decades in agriculture, livestock and household products even some of them are persistent in the environment so can be bioaccumulated in the food chain with observable effect after many yea rs of their a pplication [1]. Pesticides improper and extensive uses caused an inevitable pollution to soil, air, water and food with a detrimental hazard to non-target organisms and populations [2]. Pesticides a re known to impair the normal development of the newly born especially most of the organ systems as the immune, digestive, central nervous and res piratory systems during such period still immature so postnatal exposure to such pesticides needed to be studied [3]. These chemicals mainly affect the developing orga nisms than adults because they are so sensitive during such stage of development, less efficient protective mechanisms as DNA repair mechanisms, ill developed immune system and the capability of detoxifying enzymes are notfullyfunctional in the fetuses so a brief exposure may cause permanent teratogenic effects [4]. Moreover some of pesticides considered as hormone disrupters and such hormones are essential in tissue differentiation especiallyin the earlystages of embryonic development so abnormal development may occur upon excessive exposure to such pesticides [5].

Although copper considered as an essential metal and involved in most of physiological functions but excess copper may be toxic and interfere enzyme activities [6], copper may be found in different forms as copper oxychloride that considered as a broads pectrum fungicide that improve different crops productivity [7]. Copper oxychloride toxicity in non-target organisms occurs through 
promoting the oxidative stress as it accumulates in various tissues as a heavy metal causing cellular damage due to release of ROS through Fenton reaction [8] that may also cause hepatocellular neoplasia, kidney dysfunction and hemolytic a nemia [9] and to our knowledge there is a little information about postnatal toxic effect of copper oxychloride, so we make this trial about this effect.

\section{Materials and methods}

\subsection{Pesticide}

Copral 84.3\% WP (Copper oxychloride): Light green wettable powder (WP) with slight chlorine odor were kindly obtained from Central Agricultural Pesticide Laboratory, Ad Doki, Giza, Giza Governorate after HPLC a nalysis to confirm the copper oxychloride percentage

\subsection{Experimental animals}

Albino rats of both sex obtained from Experimental Unit in the Faculty of Pharmacy, Mansoura University; Animals weighed about $150 \pm 10$ g and were obviously healthy then grouped and housed in plastic cages with soft wood shavings as a bedding material then adapted for 2 weeks and maintained on a balanced ration before the experiment.

\subsection{Experimental design}

Eighteen pregnant female albino rats were separated into three groups with six female for each whereas the duration of exposure designated to be from the day of parturitiontill weaning ( 21 day postpartum). The female rats were treated orally with copper oxychloride with 0 , 73,5 and $147 \mathrm{mg} / \mathrm{kg}$ bw. during lactation period, the neonates litter size recorded and both da ms and neonates weighed daily and kept under observation until weaning (21 day postpartum) the day of sacrifice

\subsection{Clinical signs}

The treated dams and neonates observed daily throughout the experimental period for any abnormal behavior, findings or alteration.

\subsection{Maternal body weight gain}

The initial body weight determined and then throughout the experiment the body weight calculated before each administration [10]. The body weight gain \% determined according to the following formula:-

Body weight gain $\%=\frac{\text { Final body wt }- \text { initial body weight }}{\text { initial body weight }} \times 100$

\subsection{Sample collection}

At day 21 postpartum, dams and weaned rats euthanized with thiopental $\mathrm{Na}(40 \mathrm{mg} / \mathrm{Kg}$ i.p).

For hematological examinations fresh blood sample collected from the heart with a sterile syringe and then collected in centrifuge tubes contain K3EDTA as anticoagulant.
For biochemical analysis fresh blood collected in gel tube (not contain anticoagulant) for serum separation in centrifuge at $3000 \mathrm{rpm}$ for 15 minutes then stored at $-20^{\circ} \mathrm{C}$ in Eppendorf tubes.

For Oxidative stress determination liver sample removed from dams and weaned rats and washed with saline solution then one gram of tissues homogenized in falcon tube with $9 \mathrm{ml}$ ice cold phosphate puffer (PBS) PH7.4 through homogenizer then centrifuged at $3000 \mathrm{rpm}$ for about 15 minutes at $4^{\circ} \mathrm{C}$, the supernatant separated, collected and stored at $-20^{\circ} \mathrm{C}$ in Eppendorf tubes [11].

For his topathological examination liver, kidney, spleen and brain specimen from both dams and weaned rats collected and kept in $10 \%$ neutral buffered formalin.

\subsection{Hematological examination}

Blood sample a nalysis carried out by Mindray BC-1800 hematological analyzer whereas hemoglobin $(\mathrm{Hb})$, red blood cell count (RBC), hematocrit (HCT), mean corpuscular volume (MCV), mean corpuscular hemoglobin concentration ( $\mathrm{MCHC}$ ) and mean corpuscular hemoglobin $(\mathrm{MCH})$ evaluated besides total and differential white blood cells were also measured [12].

\subsection{Biochemical analysis}

\subsubsection{Metabolic, kidney and liver function biomarkers}

Gamma glutamyl transferase activity, Alanine aminotransferase activity, serum Glucose, serum total protein, serum albumin, serum creatinine, serum urea and serum cholesterol level were measured.

\subsubsection{Antioxidant and oxidative stress biochemical analysis}

Liver homogenate were analyzed for GSH, GST, SOD, CAT and MDA

\subsection{Histopathological examination}

Specimens from liver, kidney, spleen and brain were fixed in $10 \%$ formalin and $5 \mu$ thickness sections of specimens prepared then stained with hematoxylin and eosin (H\&E) and examined microscopically [13].

\subsection{Statistical analysis}

Statistical analyses were carried out using SPSS softwa re program (13, USA). Homogeneity of the groups was tested by Kruskal Walis test, and one-way ANOVA was used to define significance between groups at $p<0.05$ [14]

\section{RESULTS}

\section{1. Postnatal maternal and suckling pups' clinical signs after exposure to $\mathrm{COC}$}

Copper oxychloride treated lactating females at the higher doses showed signs of severe depression, decrease in the suckling times and left the suckling fetuses a way of them most of time especially $\left(1 / 10\right.$ of $\left.L D_{50}\right)$, signs illustrated in figure (1). 


\subsection{Postnatal maternaland suckling pups body weight gain\% upon exposure to $\mathrm{COC}$}

For lactating dams and suckling pups the results showed a relative significant decrease in the body weight gain in all trea ted groups throughout the study in respect to the control group es pecially higher dose group of $1 / 10 L_{50}$ of $\mathrm{COC}$ and results illustrated by tables (1) and (2) .

Table 1. The initial and final body weight mean and body weight gain $\%$ in lactating female rats administered orally different doses of copper oxychloride postnatally from 0th to 21th days postpartum daily in comparison to the control group (mean $\pm \mathrm{SE}$ ).

\begin{tabular}{llll} 
Group & $\begin{array}{l}\text { Mean Initial } \\
\text { body weight }\end{array}$ & $\begin{array}{l}\text { Mean Final } \\
\text { body weight }\end{array}$ & $\begin{array}{l}\text { Body } \\
\text { weight } \\
\text { gain \% }\end{array}$ \\
\hline Control & $158.67 \pm 2.33$ & $206.67^{\mathrm{a}} \pm 0.88$ & 30.25 \\
$\begin{array}{l}\text { Group 1/10 } \\
\text { of COC LD }\end{array}$ & $157.33 \pm 2.60$ & $185.21^{\mathrm{d}} \pm 1.53$ & 17.72 \\
$\begin{array}{l}\text { Group 1/20 } \\
\text { of COC LD }\end{array}$ & $156.33 \pm 1.76$ & $195.33^{\mathrm{b}} \pm 1.45$ & 24.95 \\
\hline
\end{tabular}

A, b, c, d: Different letters are significantly different between groups at $\mathrm{P} \leq 0.05$

Table 2. The initial and final body weight mean and body weight gain $\%$ in suckling fetuses of maternally treated dams orally with different doses of copper oxychloride postnatally from 0th to 21th days postpartum daily in comparison to the control group (mean $\pm \mathrm{SE}$ ).

$\begin{array}{llll} & \begin{array}{l}\text { Mean } \\ \text { Initial } \\ \text { body } \\ \text { weight }\end{array} & \begin{array}{l}\text { Mean Final } \\ \text { body weight }\end{array} & \begin{array}{l}\text { Body weight } \\ \text { gain \% }\end{array} \\ \begin{array}{l}5.47 \pm 0.12 \\ \text { Control }\end{array} & 34.83^{\mathrm{a}} \pm 0.73 & 536.75 \\ \begin{array}{l}\text { Group } 1 / 10 \text { of } \\ \text { COC LD }\end{array} & 5.63 \pm 0.22 & 25.68^{\mathrm{c}} \pm 1.45 & 355.95 \\ \begin{array}{l}\text { Group } 1 / 20 \text { of } \\ \text { COC LD }\end{array} & 5.59 \pm 0.24 & 31.67^{\mathrm{b}} \pm 0.88 & 466.55 \\ & & & \\ & & & \end{array}$

A, b, c, d: Different letters are significantly different between groups at $\mathrm{P} \leq 0.05$.

Table 3. The postnatal maternal liver and kidney biomarkers changes after administration of different doses of COC beside the combined group orally from 0th - 21th days postpartum daily in comparison to the control group.

$\begin{array}{cccccc} & \begin{array}{c}\text { ALT } \\ (\mathrm{U} / \mathrm{I})\end{array} & \begin{array}{c}\text { AST } \\ (\mathrm{U} / \mathrm{I})\end{array} & \begin{array}{c}\text { GGT } \\ (\mathrm{U} / \mathrm{I})\end{array} & \begin{array}{c}\text { Urea } \\ (\mathrm{mg} / \mathrm{dl})\end{array} & \begin{array}{c}\text { Creatin } \\ \text { ine } \\ (\mathbf{m g} / \mathbf{d l})\end{array} \\ \text { Control } & \begin{array}{c}24.06^{\mathrm{c}} \\ \pm 1.97^{3}\end{array} & \begin{array}{c}34.67^{\mathrm{d}} \\ \pm 1.7\end{array} & \begin{array}{c}16.63^{\mathrm{c}} \\ \pm 2.49\end{array} & \begin{array}{c}39.33^{\mathrm{c}} \\ \pm 0.85\end{array} & \begin{array}{c}0.56^{\mathrm{b}} \\ \pm 0.02\end{array} \\ & & & & & \\ \text { Group } & 47.37^{\mathrm{a}} & 62.96^{\mathrm{b}} & 37.97^{\mathrm{a}} & 66.82^{\mathrm{a}} & 1.23^{\mathrm{ab}} \\ 1 / 10 \text { of } & \pm 3.79 & \pm 1.82 & \pm 2.19 & \pm 1.43 & \pm 0.19 \\ \text { COC } & & & & & \\ \text { LD } & & & & & \\ \text { Group } & 32.3^{\mathrm{b}} & 43.37^{\mathrm{c}} & 24.37^{\mathrm{b}} & 38.65^{\mathrm{c}} & 0.64^{\mathrm{b}} \\ 1 / 20 \text { of } & \pm 1.52 & \pm 1.16 & { }^{\mathrm{c}} \pm 2.13 & \pm 3.73 & \pm 0.04 \\ \text { COC } & & & & & \end{array}$

Table 4. The postnatal maternal biochemical metabolic biomarkers changes after administration of different doses of $\mathrm{COC}$ beside the combined group orally from 0th - 21th days postpartum daily in comparison to the control group.

\begin{tabular}{|c|c|c|c|c|c|c|}
\hline & $\begin{array}{l}\text { Glucose } \\
\text { (mg/dl) }\end{array}$ & & $\begin{array}{l}\text { Cholest } \\
\text { erol } \\
(\mathrm{mg} / \mathrm{dl})\end{array}$ & $\begin{array}{l}\text { Protei } \\
\mathbf{n} \\
\text { (g/dl) }\end{array}$ & $\begin{array}{l}\text { Albumin } \\
(\mathrm{g} / \mathrm{dl})\end{array}$ & $\begin{array}{l}\text { Globulin } \\
\text { (g/dl) }\end{array}$ \\
\hline Control & $\begin{array}{l}152.47 \\
\pm 2.66\end{array}$ & a & $\begin{array}{l}93.9 \\
\pm 1.84\end{array}$ & $\begin{array}{l}8.53^{a} \\
\pm 0.52\end{array}$ & $\begin{array}{l}5.77 \\
\pm 0.45\end{array}$ & $\begin{array}{l}2.77^{a} \\
\pm 0.28\end{array}$ \\
\hline $\begin{array}{l}\text { Group } 1 / 10 \\
\text { of } C O C L_{50}\end{array}$ & $\begin{array}{l}84.67 \\
\pm 3.73\end{array}$ & $d$ & $\begin{array}{l}63.33^{d} \\
\pm 2.05\end{array}$ & $\begin{array}{l}5.41^{c} \\
\pm 0.12\end{array}$ & $\begin{array}{l}3.43^{c d} \\
\pm 0.57\end{array}$ & $\begin{array}{l}1.97^{a b} \\
\pm 0.26\end{array}$ \\
\hline $\begin{array}{l}\text { Group } 1 / 20 \\
\text { of } C O C L D_{50}\end{array}$ & $\begin{array}{l}137.13 \\
\pm 2.4\end{array}$ & b & $\begin{array}{l}85.34^{b} \\
\pm 2.78\end{array}$ & $\begin{array}{l}6.83^{b} \\
\pm 0.21\end{array}$ & $\begin{array}{l}5.03 \text { ab } \\
\pm 0.56\end{array}$ & $\begin{array}{l}1.81 \text { ab } \\
\pm 0.42\end{array}$ \\
\hline
\end{tabular}

A, b, c, d: Different letters are significantly different between groups at $\mathrm{P} \leq 0.05$

Table 5. The biochemical liver and kidney biomarkers changes in maternally treated suckling fetuses with different doses of COC orally from 0th - 21th days postpartum daily in comparison to the control group.

\begin{tabular}{|c|c|c|c|c|}
\hline & $\begin{array}{l}\text { ALT } \\
(\mathrm{U} / \mathrm{I})\end{array}$ & $\begin{array}{l}\text { GGT } \\
(\mathbf{U} / \mathbf{I})\end{array}$ & $\begin{array}{l}\text { Urea } \\
(\mathrm{mg} / \mathrm{dl})\end{array}$ & $\begin{array}{l}\text { Creatinine } \\
(\mathrm{mg} / \mathrm{dl})\end{array}$ \\
\hline \multirow[t]{2}{*}{ Control } & $35.27^{c}$ & $24.30^{c}$ & $47.33^{c}$ & $0.69^{c}$ \\
\hline & \pm 1.22 & \pm 0.96 & \pm 1.65 & \pm 0.02 \\
\hline Group 1/10 & $60.98^{a}$ & $54.93^{a}$ & $77.60^{a}$ & $1.79^{a}$ \\
\hline of COC LD 50 & \pm 1.53 & \pm 1.08 & \pm 1.60 & \pm 0.06 \\
\hline Group 1/20 & $44.48^{b}$ & $31.25^{b}$ & $55.40^{b}$ & $0.87^{b}$ \\
\hline of $C O C L_{50}$ & \pm 0.51 & \pm 1.14 & \pm 2.15 & \pm 0.05 \\
\hline
\end{tabular}

A, b, c, d: Different letters are significantly different between groups at $\mathrm{P} \leq 0.05$.

Table 6. The biochemical oxidative stress biomarkers changes in lactating dams after adminis tration of different doses of COC orally from 0th - 21th days postpartum daily in comparison to control group.

\begin{tabular}{|c|c|c|c|c|c|}
\hline Groups & $\begin{array}{l}\text { GSH } \\
\mathrm{mg} / \mathrm{g} \text {. } \\
\text { tissue }\end{array}$ & $\begin{array}{l}\text { GST } \\
\text { U/g. } \\
\text { tissue }\end{array}$ & $\begin{array}{l}\text { SOD } \\
\mathrm{U} / \mathrm{g} \text {. } \\
\text { tissue }\end{array}$ & $\begin{array}{l}\text { CAT } \\
\text { U/g. } \\
\text { tissue }\end{array}$ & $\begin{array}{l}\text { MDA } \\
\text { nmol/g. } \\
\text { tissue }\end{array}$ \\
\hline Control & $\begin{array}{l}28.69^{a} \\
\pm 0.95\end{array}$ & $\begin{array}{l}10.78^{a} \\
\pm 0.81\end{array}$ & $\begin{array}{l}27.42^{\mathrm{a}} \\
\pm 1.04\end{array}$ & $\begin{array}{l}17.96^{a} \\
\pm 0.94\end{array}$ & $\begin{array}{l}30.97 \\
c \\
\pm 0.93\end{array}$ \\
\hline $\begin{array}{l}\text { Group } \\
1 / 10 \text { of }\end{array}$ & $\begin{array}{l}14.86^{c} \\
\pm 0.97\end{array}$ & $\begin{array}{l}4.68^{c} \\
\pm 0.42\end{array}$ & $\begin{array}{l}14.01^{c} \\
\pm 1.33\end{array}$ & $\begin{array}{l}11.80^{b c} \\
\pm 0.78\end{array}$ & 71.75 \\
\hline $\mathrm{COC} \mathrm{LD}_{50}$ & & & & & \pm 2.04 \\
\hline $\begin{array}{l}\text { Group } \\
1 / 20 \text { of } \\
C O C L_{50}\end{array}$ & $\begin{array}{l}22.91^{b} \\
\pm 1.43\end{array}$ & $\begin{array}{l}7.93^{b} \\
\pm 0.46\end{array}$ & $\begin{array}{l}20.15^{b} \\
\pm 2.26\end{array}$ & $\begin{array}{l}13.81^{b} \\
\pm 0.54\end{array}$ & $\begin{array}{l}56.37 \\
b \\
\pm 2.33\end{array}$ \\
\hline
\end{tabular}

A, b, c, d: Different letters are significantly different between groups at $P \leq 0.05$

\subsection{Postnatal maternaland suckling fetuses' biochemical analysis}

\subsection{Metabolic, liver and kidney functions' biomarkers in lactating dams and suckling pups}

Estimation of Glucose, cholesterol, total protein, albumin, globulin, ALT, AST, GGT, urea and creatinine had 
been carried on lactating female rats after administration of different doses of COC (1/10 LD 50 and $1 / 20 L_{50}$ of COC equivalent to $147 \mathrm{mg} / \mathrm{kg} \mathrm{Bw}$. and $73.5 \mathrm{mg} / \mathrm{kg} \mathrm{Bw}$. respectively) orally from 0th - 21th days postpartum daily in comparison to control group.

Table 7. Biochemical oxidative stress biomarkers changes in suckling fetuses of maternally treated dams with different doses of $\mathrm{COC}$ orally from 0 th -21 th days postpartum daily in comparison to control group.

\begin{tabular}{|c|c|c|c|c|c|}
\hline Groups & $\begin{array}{l}\text { GSH } \\
\mathrm{mg} / \mathrm{g} . \\
\text { tissue }\end{array}$ & $\begin{array}{l}\text { GST } \\
\text { U/g. } \\
\text { tissue }\end{array}$ & $\begin{array}{l}\text { SOD } \\
\mathrm{U} / \mathrm{g} \text {. } \\
\text { tissue }\end{array}$ & $\begin{array}{l}\text { CAT } \\
\text { U/g. } \\
\text { tissue }\end{array}$ & $\begin{array}{l}\text { MDA } \\
\text { nmol/g. } \\
\text { tissue }\end{array}$ \\
\hline Control & $\begin{array}{l}18.94^{\mathrm{a}} \\
\pm 1.10\end{array}$ & $\begin{array}{l}8.04^{\mathrm{a}} \\
\pm 0.44\end{array}$ & $\begin{array}{l}14.63^{\mathrm{a}} \\
\pm 1.17\end{array}$ & $\begin{array}{l}9.37^{\mathrm{a}} \\
\pm 0.51\end{array}$ & $\begin{array}{l}49.45^{\mathrm{c}} \\
\pm 0.96\end{array}$ \\
\hline $\begin{array}{l}\text { Group } 1 / 10 \\
\text { of COC LD } \text { D }_{50}\end{array}$ & $\begin{array}{l}11.44^{\mathrm{c}} \\
\pm 0.62^{2}\end{array}$ & $\begin{array}{l}4.17^{\mathrm{d}} \\
\pm 0.50\end{array}$ & $\begin{array}{l}8.22^{\mathrm{b}} \\
\pm 0.44\end{array}$ & $\begin{array}{l}6.12^{b} \\
\pm 0.59\end{array}$ & $\begin{array}{l}87.40^{\mathrm{a}} \\
\pm 1.61\end{array}$ \\
\hline $\begin{array}{l}\text { Group } 1 / 20 \\
\text { of COC LD } 50\end{array}$ & $\begin{array}{l}16.79^{a b} \\
\pm 1.15\end{array}$ & $\begin{array}{l}6.66^{b} \\
\pm 0.27\end{array}$ & $\begin{array}{l}12.02^{\mathrm{a}} \\
\pm 1.29\end{array}$ & $\begin{array}{l}9.06^{\mathrm{a}} \\
\pm 0.10\end{array}$ & $\begin{array}{l}66.36^{b} \\
\pm 1.58\end{array}$ \\
\hline
\end{tabular}

A, b, c, d: Different letters are significantly different between groups at $\mathrm{P} \leq 0.05$.

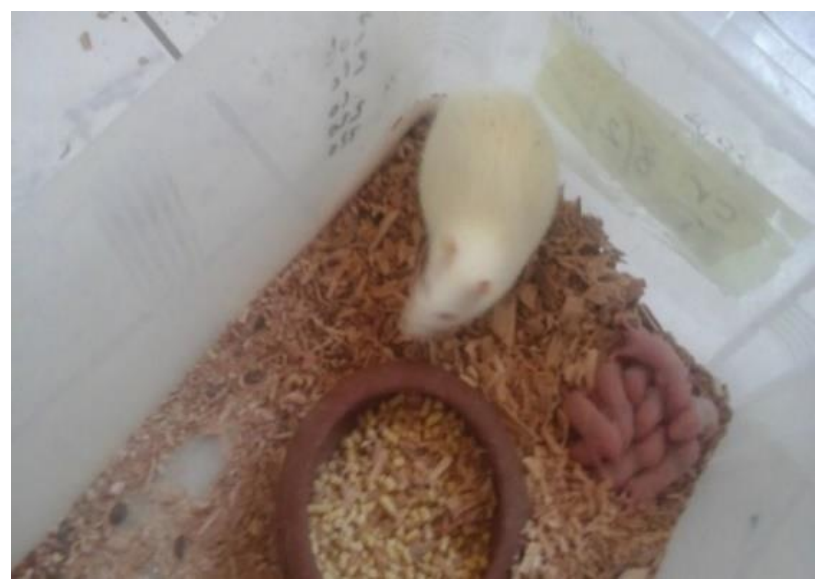

Figure 1. Lactating female treated with $1 / 10$ LD50 COC displayed severe depression and decrease in the suckling times

For metabolic biomarkers in lactating dams the results showed that a significant decrease in glucose, cholesterol, total protein, albumin and gl obulin in all treated groups in res pect to the control group es pecially group of $1 / 10 L D_{50}$ of COC equi valent to $147 \mathrm{mg} / \mathrm{kg} \mathrm{Bw}$. in comparison to control.

For liverfunction biomarkers there was a significant increase of all biomarkers (ALT, AST and GGT) in most of treated groups in comparison to the control group es pecially higher dose group $\left(1 / 10 L D_{50}\right.$ of COCequivalent to $147 \mathrm{mg} / \mathrm{kg} \mathrm{Bw}$.) in comparison to the control group.

For kidney function biomarkers there was a significant increase in blood urea nitrogen and creatinine in most of treated groups in comparison to the control group especially group $1 / 10 \mathrm{LD}_{50}$ of COC equivalent to $147 \mathrm{mg} / \mathrm{kg}$ Bw in respect to the control group. The results illustrated in tables (3) and (4).
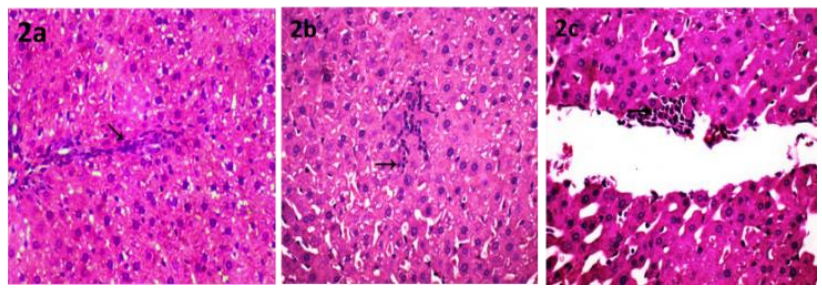

Figure 2. Shows (2a) degenerative changes and intralobular histiocytic infiltration in the hepatic tissue (arrow) in lactating dams treated with 1/10 $\mathrm{LD}_{50}$ of COC orally from 0th - 21th days postpartum (HE, 400x). (2b) liver is showing plasma cell infiltrate (arrow) with lymphocytes and intralobular fibroblastic proliferation in lactating dams treated with $1 / 20 \operatorname{LD}_{50}$ of $\mathrm{COC}$ orally from 0th - 21th days postpartum (HE, 400x). (c) Focal histiocytic infiltration in the hepatic tissue (arrow) in suckling fetuses of treated dams with $1 / 10 \mathrm{LD}_{50}$ of COC orally from 0th - 21th days postpartum (HE, 400x).

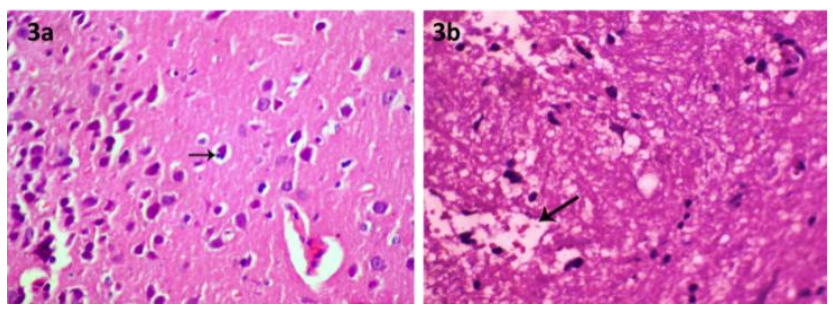

Figure 3. Shows (3a) Neuronal necrosis and neuronophagia in the brain tissue (arrow) in lactating dams treated with $1 / 10 \mathrm{LD}_{50}$ of COC orally from 0th - 21th days postpartum (HE, 400x). (3b) Focal hemorrhagic area in the brain tissue (arrow) in suckling fetuses of treated dams with $1 / 10 L_{50}$ of COC orally from 0th - 21th days postpartum (HE, 400x).

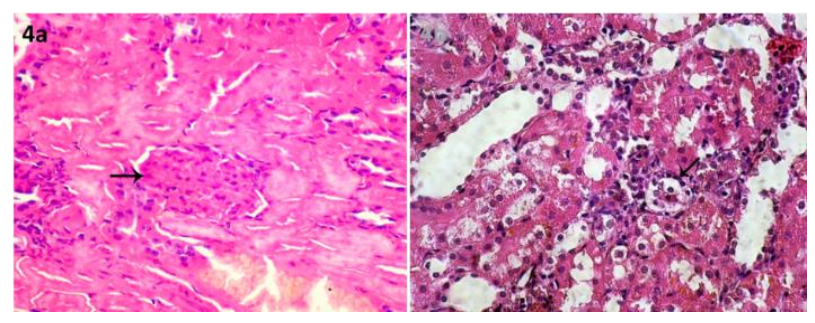

Figure 4. Shows (4a) Proliferation of renal glomeruli (arrow) and degenerative changes in renal tubular epithelium in lactating dams treated with $1 / 10 \mathrm{LD}_{50}$ of $\mathrm{COC}$ orally from 0th - 21th days postpartum (HE, 400x). (4b) Degeneration in the renal tubular epithelium and interstitial lymphocytic infiltration (arrow) in suckling fetuses of treated dams with $1 / 10 \mathrm{LD}_{50}$ of COC orally from 0th - 21th days postpartum (HE, 400x).

Liver and kidney functions estimated in suckling fetuses of maternally treated dams for the same groups and there was a significant increase in ALT, GGT, BUN and creatinine in all ma ternally treated groups in comparison to the control group especially higher dose group of $1 / 10 L_{50}$ of COC equivalent to $147 \mathrm{mg} / \mathrm{kg} \mathrm{Bw}$. as illus trated in table (5).

\subsubsection{Oxidative stress biomarkers in lactating dams and suckling fetuses}

For lactating dams there was a significant decrease in GSH, GST, SOD and CAT in all treated groups when compared with the control group especially higher dose group (1/10 LD $\mathrm{L}_{50}$ of COC equivalent to $147 \mathrm{mg} / \mathrm{kg} \mathrm{Bw}$.) in comparison to the control group.

MDA showed a significant increase in all treated groups in respect to the control group especially groups of $1 / 10$ 
$\mathrm{LD}_{50}$ of COC equivalent to $147 \mathrm{mg} / \mathrm{kg} \mathrm{Bw}$, in comparis on to the control group, such results illustrated in table (6).

For suckling fetus es of maternally treated da ms there was a significant decrease in GST, GSH, SOD and CAT in most of treated groups when compared with the control group especially higher dose group $\left(1 / 10 \mathrm{LD}_{50}\right.$ of COC equivalent to $147 \mathrm{mg} / \mathrm{kg} \mathrm{Bw}$.) in comparison to the control group.

On the other hand, MDA showed a significant increase in all maternally treated groups in respect to the control group especiallygroups of $1 / 10 \mathrm{LD}_{50}$ of $\mathrm{COC}$ equivalent to $147 \mathrm{mg} / \mathrm{kg} \mathrm{Bw}$. and results shown in table (7).
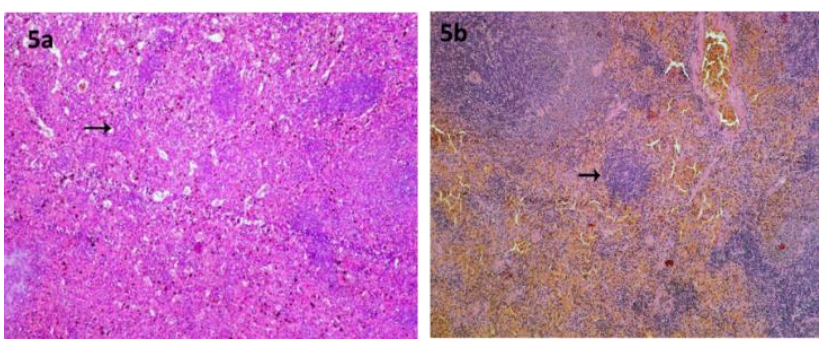

Figure 5. Shows (5a) Marked lymphoid depletion in the splenic tissue in lactating dams treated with $1 / 10 L_{50}$ of $C O C$ orally from 0th - 21th days postpartum (HE, 100x). (5b) Marked lymphoid tissue depletion in the splenic tissue (arrow) in suckling fetuses of treated dams with $1 / 10 L_{50}$ of COC (HE, 100x).

Table 8. The hematological finding in lactating dams after administration of different doses of COC orally from 0th - 21th days postpartum daily in comparison to control group.

\begin{tabular}{|c|c|c|c|c|c|c|c|}
\hline & $\begin{array}{l}\text { RBCs (million } \\
\text { cells/uL) }\end{array}$ & $\mathrm{Hb}(\mathrm{g} / \mathrm{dL})$ & PCV (\%) & MCV (fL) & MCH (pg) & $\mathrm{MCHC}(\mathrm{g} / \mathrm{dL})$ & $\begin{array}{l}\text { TOTAL WBCs } \\
(1000 \\
\text { cells/uL) }\end{array}$ \\
\hline Control & $8.42^{a} \pm 0.02$ & $14.76^{a} \pm 0.05$ & $45.75^{a} \pm 0.05$ & $54.34 \pm 0.20$ & $17.53 \pm 0.10$ & $32.26 \pm 0.10$ & $7.67^{b} \pm 0.10$ \\
\hline 1/10 LD 50 of COC & $6.67^{c} \pm 0.06$ & $11.30^{d} \pm 0.30$ & $36.47^{c} \pm 0.08$ & $54.72 \pm 0.58$ & $16.96 \pm 0.61$ & $30.98 \pm 0.79$ & $8.85^{a} \pm 0.05$ \\
\hline $1 / 20$ LD50 of COC & $7.30^{b} \pm 0.23$ & $13.05^{c} \pm 0.15$ & $41.34^{b} \pm 1.21$ & $56.62 \pm 0.31$ & $17.90 \pm 0.48$ & $31.61 \pm 0.70$ & $7.53^{b} \pm 0.12$ \\
\hline
\end{tabular}

A, b, c, d: Different letters are significantly different between groups at $\mathrm{P} \leq 0.05$.

\subsection{Hematological Finding in lactating dams}

The results showed that there was a significant decrease in the total RBCs count, $\mathrm{Hb}$ in the groups treated with $1 / 10 L D_{50}$ and $1 / 20 L D_{50}$ of COC equivalent to 147 $\mathrm{mg} / \mathrm{kg} \mathrm{Bw}$. and $73.5 \mathrm{mg} / \mathrm{kg}$ Bw. respectively in comparison to the control group.

On the other hand, total leukocytic count showed a significant increase in the group treated with $1 / 10 \mathrm{LD}_{50}$ of COC equivalent to $147 \mathrm{mg} / \mathrm{kg} \mathrm{Bw}$. in comparison to the control group. However, there was no significance change in all treated groups in PCV, MCV, MCH and MCHC levels in res pect to the control values. The results illustrated in ta ble (8).

\subsection{Histopathological findings}

The histopathological changes was observed in lactating dams and suckling fetuses of maternally treated dams with different doses of $\mathrm{COC}(147 \mathrm{mg} / \mathrm{kg}$ Bw. and 73.5 $\mathrm{mg} / \mathrm{kg} \mathrm{Bw}$.) in comparison to the control group and the results showed that there was a clear pathological changes es pecially at the higher doses groups and the combined dose group.

For lactating dams treated with different doses of $\mathrm{COC}$ there was degenerative changes and intralobular histiocytic infiltration with intralobular fibroblastic proliferation in the hepatic tissue, results illustrated in fig (2).
For the suckling fetuses of treated dams with different doses of COC there was focal histiocytic and lymphocytic infiltration besides congestion of portal vein and margination of leukocytes in a dose dependent manner, results illustrated in fig (2).

For lactating da ms treated with different doses of $\mathrm{COC}$ there were neuronal necrosis, neuronophagia and astrocytosis in the brain tissue with degenerative changes of purkinje cells incerebellum, results illus trated in fig (3).

For the suckling pups of treated da ms with different doses of COC there was focal edema in the neuropils (nonmyel inated nerve fibers) with focal hemorrhagic areas in the brain tissue in a dose dependent manner, results illustrated in fig (3).

For lactating dams treated with different doses of $\mathrm{COC}$ there was fibrous tissue proliferation of renal glomeruli with degenerative changes in renal tubular epithelium, results illustrated in fig (4).

For the suckling fetuses of treated dams with different doses of $\mathrm{COC}$ there was degeneration in the renal tubular epithelium and interstitial lymphocytic infiltration with congestion of the renal glomeruli in a dose dependent manner, results illustrated in fig (4). 
For la ctating dams treated with different doses of COC there was marked lymphoid depletion in the splenic tissue, results illustrated in fig (5)

For the suckling pups of treated dams with different doses of COC there was sever Iymphoid depletion with congestion of the splenic sinusoids in a dose dependent manner, results illustrated in fig (5).

\section{DISCUSSION}

All lactating dams and suckling pups of maternally treated dams with different doses of COC (147 and 73.5 $\mathrm{mg} / \mathrm{kg} \mathrm{Bw}$. COC) throughout the study showed a significant relative decrease in the body weight and increase in the liver function enzymes and oxidative biomarkers with significant pathological changes in different organs in a dose dependent manner in respect to the control group. The postnatal toxicity may be attributed to the maternal exposure to different pesticides during the lactation period that may accumulate it in their fat tissues and also in lipid fraction in milk so increase in the daily exposure to such pesticides may el evate its level in milk significantly and so exert its effect in the suckling pups [15], moreover milk considered as the sole source of essential nutrients in the suckling pups soanymodification in the milk composition or decrease in its quantity may affect such pups therefore breastmilkmay be used as a biomarker for the postnatal toxicity [16].

The immune, digestive, central nervous and res piratory sys tems a re all susceptible to pesticides postnatally as they are immature for a while after the birth [3], also metals as copper originated from exogenous sources as contaminated food or water transferred to milk from the maternal blood through different milk constituents as fat and casein [17].

The body weight, all lactating dams and suckling pups of maternally treated dams with different doses of COC (147 and $73.5 \mathrm{mg} / \mathrm{kg} \mathrm{Bw.} \mathrm{COC)} \mathrm{throughout} \mathrm{the} \mathrm{study}$ showed a significant relative decrease in the body weight in a dose dependent manner in res pect to the control group. This result could be explained as the exposure to excess copper in diet for 9 weeks significantly decrease the final body weights in rats [18] Also, the copper monochloride with different concentrations $(5,20$ and $80 \mathrm{mg} / \mathrm{kg}$ orally daily) had a significant decrease in the body weight and food consumption [19] This reduction of the body weight might be due to liver damage as it considered as the major target organ in most of the toxicity studies that decrease the food consumption and body weight [20].

Notably, the biochemical changes in all lactating dams treated with different doses of COC (147 and $73.5 \mathrm{mg} / \mathrm{kg}$ Bw. $\mathrm{COC}$ ) throughout the study showed a significant decrease of all metabolic biochemical parameters as glucose, cholesterol, total protein, albumin and gl obulin in comparison to the control group. Similar study found the toxic effect of copperin Cyprinus carpio for 30 days that resulted ina significant decrease in the level of glucose, total protein and cholesterol [21]. Also, this may be because of the deleterious effect of excess copper in organisms as it stimulates free radical production and lipid peroxidation in the living cell and disturbs the whole body antioxidant capacitywith hepatic and renal insufficiency [22].

Furthermore, all lactating dams and suckling pups treated with different doses of COC (147 and $73.5 \mathrm{mg} / \mathrm{kg}$ Bw. COC) throughout the study showed a significant increase in ALT, GGT, AST, Urea and Creatinine that reflect a state of hepa toxicity and nephrotoxicity after exposure to COC in comparison to the control group. Similar study recorded the hepatotoxicity of $\mathrm{COC}$ in rats in a toxicological study at dose level 500, 1000 and $2000 \mathrm{mg} / \mathrm{kg} \mathrm{Bw}$. for 90 days [23]. Moreover, the COC may harm human and public health causing hepatotoxicity with a significant increase in ALT and AST. Moreover copper nephrotoxicity and renal dysfunction reported through multiple studies after prolonged exposure to copper as copper accumulated in the proximal renal tubules causing a dose dependent increase in the renal serum creatinine and urea levels and decrease in protein level due to proteinuria and liver damage [24].

For the oxidative stress biomarkers, all lactating dams and suckling pups trea ted with different doses of COC (147 and $73.5 \mathrm{mg} / \mathrm{kg} \mathrm{Bw}$. COC showed a dose dependent decrease in GSH, GST, SOD and CAT and increase in MDA. Similarly, the exposure to copper oxychloride had a significant oxidative stress damage to cells with decrease of GPx, CAT levels and increase in LPO content [8]. This injury could explain as excess copper stimulates free radical productionin the living cell through Fenton reaction with lipid peroxidation and disturbs the whole body antioxidant capacity [22], also the liver considered as the major organ implicated in the xenobiotics biotransformation and oxidative reactions with subsequent free radical production and although has efficient antioxidant defense system it may be overwhelmed by the excessive ROS production [25].

For the hematological findings, all lactating dams treated with different doses of COC (147 and $73.5 \mathrm{mg} / \mathrm{kg}$ Bw. COC) showed that there was a significant decrease in RBCs count, $\mathrm{Hb}$ content and PCV in all treated dams with el evation in leukocytic counts and as well [9] reported that copper oxychloride may accumulate in various tissues as a heavy metal and cause hemolytic a nemia, also [26] found that copper may promote hemolysis anemia and hemorrhage with abnormal high blood Cu+ levels. However, the el evation of the leukocyte counts considered as a precise indicator of the immune system, defense mechanism and increase in the inflammatory response upon exposure to environmental pollutant and pesticides [27].

For the histopathological changes COC treated rats' showed a significant increase in the histopathological changes in the hepatic, brain, renal and splenic tissues due to the accumulation of $\mathrm{COC}$ inva rious tissues causing their 
dysfunction with cellular degeneration [9]. This also could be explained as liver and kidneys perform various functions that associated with the metabolism of xenobiotics and considered as the major detoxifying organs and affected after stress caused by toxicants [28]. Moreover copper may cause necrosis in the neural tube with mitochondrial vacuolization after accumulation in the brain tissue [29], finally lymphoid depletion in splenic tissue seemed to be multifactorial due to either apoptosis of short lived lymphocytes or decreased in the mitotic activity in the bone marrow cells due to the toxic effect of pesticides on the splenic and bone marrow cells [30].

\section{REFERENCES}

[1] Jayaraj R, Megha P, Sreedev P. Organochlorine pesticides, their toxic effects on living organisms and their fate in the environment. Interdiscip Toxicol 2016;9:90-100. https://doi.org/10.1515/intox-2016-0012

[2] Gilden RC, Huffling K, Sattler B. Pesticides and health risks. J Obstet Gynecol Neonatal Nurs 2010;39:103-10. https://doi.org/10.1111/j.1552-6909.2009.01092.x

[3] Caserta D, Graziano A, Monte GL, Bordi G, Moscarini M. Heavy metals and placental fetal-maternal barrier: a mini-review on the major concerns. Eur Rev Med Pharmacol Sci 2013;17:2198-206.

[4] Uggini GK, Patel PV, Balakrishnan S. Embryotoxic and teratogenic effects of pesticides in chick embryos: a comparative study using two commercial formulations. Environ toxicol 2012;27:166-74. https://doi.org/10.1002/tox.20627

[5] Corcellas C, Andreu A, Máñez M, Sergio F, Hiraldo F, Eljarrat E, et al. Pyrethroid insecticides in wild bird eggs from a World Heritage Listed Park: A case study in Doñana National Park (Spain). Environ Pollut 2017;228:321-30. https://doi.org/10.1016/j.envpol.2017.05.035

[6] Laurén DJ, McDonald D. Acclimation to copper by rainbow trout, Salmo gairdneri: physiology. Can J Fish Aquat Sci 1987;44:99-104. https://doi.org/10.1139/f87-012

[7] Osman AH, El-Shama SS, Osman AS, Elhameed AKA. Toxicological and pathological evaluation of prolonged bromuconazole fungicide exposure in male rats. The Medical Journal of Cairo University 2011;79.

[8] Sevcikova M, Modra H, Blahova J, Dobsikova R, Plhalova L, Zitka $\mathrm{O}$, et al. Biochemical, haematological and oxidative stress responses of common carp (Cyprinus carpio L.) after sub-chronic exposure to copper. Veterinární Medicína 2016;61. https://doi.org/10.17221/8681-VETMED

[9] Waheed S, Kamal A, Malik RN. Human health risk from organspecific accumulation of toxic metals and response of antioxidants in edible fish species from Chenab River, Pakistan. Environ Sci Pollut Res 2014;21:4409-17. https://doi.org/10.1007/s11356-013-2385-3

[10] Bhardwaj S, Srivastava M, Kapoor U, Srivastava L. A 90 days oral toxicity of imidacloprid in female rats: morphological, biochemical and histopathological evaluations. Food chem toxicol 2010;48:1185-90. https://doi.org/10.1016/j.fct.2010.02.009
[11] Fernandez-Botran R, Gorantla V, Sun X, Ren X, Perez-Abadia $G$, Crespo FA, et al. Targeting of glycosaminoglycan-cytokine interactions as a novel therapeutic approach in allotransplantation1. Transplantation 2002;74:623-9. https://doi.org/10.1097/00007890-200209150-00007

[12] Agbasi P. U. AN, Onye J. J., Ibeawuchi C., Uzoechi S. C., Alagwu E. A., Okeke C. U., Uloneme G. C. . The effect of subchronic low dose of DDVP and sodium azid on the hematological indices of albino rats. Toxicol Physiol Biochem 2015;4:103-10.

[13] Bancroft JD, Stevens A. Theory and practice of histological techniques. 1990.

[14] Snedecor GW, \& Cochran, W. G. . Statistical Methods, eight edition. lowa state University press, Ames, lowa 1989 ..

[15] Damgaard IN, Skakkebæk NE, Toppari J, Virtanen HE, Shen H, Schramm K-W, et al. Persistent pesticides in human breast milk and cryptorchidism. Environ Health Perspect 2006;114:1133-8. https://doi.org/10.1289/ehp.8741

[16] Muller G, Hutin M-F, Burnel D, Lehr PR. Aluminum transfer through milk in female rats intoxicated by aluminum chloride. Biol Trace Elem Res 1992;34:79-87. https://doi.org/10.1007/BF02783900

[17] Gundacker C, Zödl B. Heavy metals in breast milk: implications for toxicity. Reviews in Food and Nutrition Toxicity 2005;4:1-28 https://doi.org/10.1201/9781420037524.ch1

[18] Dillard C, Tappel A. Lipid peroxidation and copper toxicity in rats. Drug Chem Toxicol 1984;7:477-87. https://doi.org/10.3109/01480548408994214

[19] Chung MK, Baek SS, Lee SH, Kim H, Choi K, Kim JC. Combined repeated dose and reproductive/developmental toxicities of copper monochloride in rats. Environl Toxicol 2009;24:31526. https://doi.org/10.1002/tox.20433

[20] Fuentealba I, Haywood S, Foster J. Cellular mechanisms of toxicity and tolerance in the copper-loaded rat. III. Ultrastructural changes and copper localization in the kidney. Br J Exp Pathol 1989;70:543.

[21] Dhanapakiam P, Ramasamy V. Toxic effects of copper and zinc mixtures on some haematological and biochemical parameters in common carp, Cyprinus carpio (Linn). J Environ biol 2001;22:105-11.

[22] Husak V. Copper and copper-containing pesticides: metabolism, toxicity and oxidative stress. Journal of Vasyl Stefanyk Precarpathian National University 2015:39-51. https://doi.org/10.15330/jpnu.2.1.38-50

[23] El-Hak HNG, Mobarak YM. The ameliorative impacts of curcumin on copper oxychloride-induced hepatotoxicity in rats. J Basic Appl Zool 2018;79:44. https://doi.org/10.1186/s41936-018-0059-x

[24] Babaknejad N, Moshtaghie AA, Shahanipour K. The toxicity of copper on serum parameters related to renal functions in male wistar rats. Zahedan J Res Med Sci 2015;15.

[25] Jasper R, Locatelli GO, Pilati C, Locatelli C. Evaluation of biochemical, hematological and oxidative parameters in mice exposed to the herbicide glyphosate-Roundup ${ }^{\circledR}$. Interdiscip Toxicol 2012;5:133-40. https://doi.org/10.2478/v10102-0120022-5 
[26] Shivanandappa T, Krishnakumari M, Majumder S. Testicular atrophy in Gallus domesticus fed acute doses of copper fungicides. Poultry Sci 1983;62:405-8. https://doi.org/10.3382/ps.0620405

[27] Yousef MI, El-Demerdash F, Kamel K, Al-Salhen K. Changes in some hematological and biochemical indices of rabbits induced by isoflavones and cypermethrin. Toxicol 2003;189:223-34. https://doi.org/10.1016/S0300$483 \times(03) 00145-8$

[28] Sancho E, Ferrando M, Fernandez C, Andreu E. Liver energy metabolism ofAnguilla anguillaafter exposure to fenitrothion. Ecotoxicol Environ Saf 1998;41:168-75. https://doi.org/10.1006/eesa.1998.1689

[29] Checiu I, Checiu M, Checiu D, Capalnasan I, Tuduce I. Investigations of teratogenic effects induced by copper upon early postimplantational mouse embryos. Annals of West University of Timişoara, ser Biology 2003;506:87-94.

[30] Turk J, Poulter L. Selective depletion of lymphoid tissue by cyclophosphamide. Clin Exp Immunol 1972;10:285. 